\title{
A Novel Non-invasive Method Allowing for Discovery of Pathologically Relevant Proteins From Small Airways
}

\section{Jörgen Östling}

PExA AB

\section{Marleen Van Geest}

Hansa Biopharma AB, Lund

Henric K Olsson

AstraZeneca Sweden: AstraZeneca AB

\section{Sven-Erik Dahlén}

Karolinska Institutet Institutet för miljömedicin: Karolinska Institutet Institutet for miljomedicin

\section{Emilia Viklund}

University of Gothenburg Institute of Medicine: Goteborgs universitet Institutionen for medicin

\section{Per Gustafsson}

Department of Pediatrics, Skövde Hospital

\section{Ekaterina Mirgorodskaya}

University of Gothenburg: Goteborgs Universitet

\section{Anna-Carin Olin ( $\square$ anna-carin.olin@amm.gu.se )}

Occupational and Environmental Medicine, Dept of Public Health and Community Medicine, Inst of Medicine, University of Gothenburg, Sweden https://orcid.org/0000-0001-6674-9020

\section{Research}

Keywords: Exhaled air, Non-volatiles, Breath, Small airways, Biomarker, Non-invasive, Asthma, Proteomics

Posted Date: September 30th, 2020

DOI: https://doi.org/10.21203/rs.3.rs-78071/v1

License: (c) (i) This work is licensed under a Creative Commons Attribution 4.0 International License. Read Full License 


\section{Abstract}

\section{Background}

Breath contains an aerosol of droplet particles, which are formed from the epithelial lining fluid when the small airways close and re-open during inhalation succeeding a full expiration. These particles can be collected by impaction using the PEXA® method (Particles in Exhaled Air), and constitute a potential source of biomarkers reflecting pathological processes in the small airways.

Objective

Our aim was to investigate if PExA method may be useful for discovery of biomarkers that reflect pathology of small airways.

Methods

10 healthy controls and 20 subjects with asthma, of whom 10 with small airway dysfunction (SAD), were examined using the PExA instrument. The samples were analysed with the SOMAscan proteomics platform (SomaLogic Inc).

Results

Two hundred-seven proteins were detected in up to $80 \%$ of the samples. Nine proteins showed differential abundance in subjects with SAD as compared to healthy controls. Two of these were less abundant (ALDOA4, C4), and seven more abundant (FIGF, SERPINA1, CD93, CCL18, F10, IgM, IL1RAP). sRAGE levels were lower in ex-smokers $(n=14)$ than in never smokers $(n=16)$. Gene Ontology (GO) annotation database analyses revealed that the PEx proteome is enriched in extracellular proteins associated with extracellular exosome-vesicles and innate immunity.

Conclusion

The applied analytical method was reproducible and allowed identification of pathologically interesting proteins in PEx samples from asthmatic subjects with small airway dysfunction. The results suggest that PEx based proteomics is an novel and promising approach to study respiratory diseases with small airway involvement.

\section{Background}

There is a growing interest in the role of small airways (inner diameter $<2 \mathrm{~mm}$ ) in asthma and other lung diseases [1]. In asthma, small airway dysfunction (SAD) is associated with more severe disease and loss of control [2-6], but has also been demonstrated in moderate and mild asthma [7]. Small airway involvement is a recognised feature of chronic obstructive lung disease (COPD) [8], and in other severe 
lung-disease including viral bronchiolitis (as observed in e.g. COVID-19), lung-fibrosis and hypersensitivity pneumonitis.

In the small airways, surfactant plays a crucial role for airway patency and innate immune responses [9]. Surfactant is a complex mixture of proteins and lipids that keeps small airways open by reducing surface tension, but it also plays an important role in innate immunity by enhancing phagocytosis of inhaled pathogens and particulate matter by special surfactant proteins [10] and by modulating immune responses [11-14]. Given it's crucial role for airway patency and host defence, knowledge of the protein and lipid composition of surfactant is surprisingly limited.

Although the small airways are a key compartment for the onset and progression of respiratory diseases such as COPD and lung-fibrosis [15], early detection of pathological processes in the small airways remains difficult mainly due to lack of methods to sample this region of the lung. One option for retrieving biological material from the small airways is through bronchoscopy with sampling of biopsies or bronchoalveolar lavage fluid, but this method is invasive and not suited for routine point-of-care situations or clinical trials. Non-invasive physiological measurements reflecting small airway lung function exist (e.g. inert-gas wash out techniques and impulse oscillometry), but these methods do not provide the molecular information about mechanisms and pathways needed to drive drug discovery and the further development of precision medicine. In particular, the introduction of biologics, targeting specific molecular pathways, have highlighted the need for biomarkers that reflect disease endotypes, to enable patient stratification.

Particles in Exhaled Air (PExA) is a novel sampling method allowing non-invasive retrieval of biological material from the small airways. In short, the method is based on impaction of an aerosol consisting of ultrafine droplets of respiratory tract lining fluid (RTLF) that are formed and exhaled after a breathing manoeuvre that promote airway closure and reopening of the small airways [16]. The PExA method has been thoroughly described by Larsson et. al. [17].

The molecular composition of PEx samples have been explored in previous studies, and 120 different proteins could be detected in PEx samples pooled from several individuals by LC/MS (21). The protein composition of these samples showed up to $80 \%$ similarities to bronchoalveolar lavage fluid (BALF).

Highly abundant proteins, like SP-A have been successfully quantified with low intra-individual variability in PEx samples from single individuals by ELISA $[17,18]$ and show good correlation to SP-A levels in BALF [19]. In the present study we sought to evaluate whether the PEx samples convey information on pathophysiological processes useful in biomarker discovery. SOMAscan (SomaLogic Inc) was identified as a potentially suitable proteomics platform for the study. As PEx samples mainly originate from the small airways, we hypothesised differences in protein composition of PEx samples would be easiest to observe between healthy subjects and patients with evidence of SAD. Based on this reasoning we chose to study the protein composition of samples from asthmatic subjects with SAD compared to that of asthmatic subjects and heathy controls without SAD. 


\section{Material And Methods \\ Study subjects}

Twenty subjects with asthma and ten healthy controls were included in the study. All were recruited from our earlier studies on asthma, or by an advertisement in a daily paper. To identify subjects with small airway dysfunction (SAD), all subjects were screened with multiple breath nitrogen wash test (MBNW), giving an index of heterogeneity of ventilation, Lung Clearance Index ( $(\mathrm{Cl})$, indicating SAD [20]. Asthma subjects were stratified into two groups, whereof one with $\mathrm{LCl} z$ score $<2$, herein referred to as $A(n=10)$, and one with $\mathrm{LCl} z$ score $>3$, herein referred to as ASAD $(n=10)$. All subjects with asthma reported a physician diagnose of asthma and were taking asthma medication regularly. We also included a control group (non-asthma) that did not report respiratory symptoms nor were taking medication for respiratory disease and had normal $\mathrm{LCl} z$ score (i.e. $\mathrm{LCl}<2)$, herein referred to as NA $(n=10)$.

Exclusion criteria were current smoking or smoking within the last 10 years or $>10$ pack-years, diagnosis of systemic inflammatory disease, cardiovascular disease or pregnancy. Demographic and clinical data including $\mathrm{LCl}$ z-scores are presented in Table 1. All participants gave their written informed consent and the study was approved by the Ethical Committee at Gothenburg University in Sweden.

\section{Clinical characterization}

Spirometry was performed according to ERS guidelines, using Spirare spirometer (Spirare, Stockholm, Sweden) Forced vital capacity (FVC) and forced expired volume in one second were expressed as a percentage of the reference value (FEV1 \% pred) derived from the ECCS/ERS reference equations [21].

Multiple Breath Nitrogen Wash-out tests were performed using the Exhalyzer ${ }^{\circledR}$ D device (Eco Medics AG, Duernten, Switzerland) and software (Spiroware 3.1) in accordance with current guidelines [22]. Z-scores were calculated as described by Kjellberg et. al. [23].

Fraction of exhaled nitric oxide (FENO) was measured once by a NIOX Mino (Aerocrine AB, Stockholm, Sweden) before spirometry following the ATS-ERS guidelines [24], except for only performing one exhalation.

A skin-prick test (SPT) to common allergens in Sweden was performed with positive result defined as a wheal diameter $\geq 3 \mathrm{~mm}$ and negative control $<3 \mathrm{~mm}$. Atopy was defined as the occurrence of at least one positive SPT wheal.

Serum samples were analysed for hsCRP and differential cell counts, using standard clinical methods.

All subjects filled out a questionnaire on medical history, smoking habits, symptoms and medication and subjects with asthma filled out Asthma Control Questionnaire, ACQ, reflecting asthma control over the 
last week [25]. The use of medication was translated to GINA step for each subject according to GINA guidelines 2016.

\section{PEx sample collection}

The PExA method and PExA 1.0 instrument was used to collect PEx samples (described in supplement). For assessment of reproducibility, $120 \mathrm{ng}$ of PEx was collected from each subject and for all other samples at least $240 \mathrm{ng}$ of PEx was collected, involving two consecutive sampling sessions with a short break in between. After collection the sample holder was transferred to a clean-air room and the substrate was excised with a scalpel from the sample holder and placed in Millipore Ultrafree-MC LH Centrifugal Filter insert (FC30LH25) and stored at $-80^{\circ} \mathrm{C}$ for further analysis. True blank samples were generated by applying the same procedure as for real samples but without a human breathing into the PExA instrument.

\section{SOMAscan analysis}

SOMAscan is a proprietary highly multiplexed, sensitive proteomic platform (SomaLogic Inc., Boulder, USA), further described in the supplement. As the SOMAscan platform developed during the study period two different versions was used; i) SOMAscan $1.1 \mathrm{~K}$ was used for the assessment of SOMAscan performance with PEx samples and SOMAscan 1.3K for the other experiments. Sample preparation is described in supplement.

\section{SOMAscan data processing}

Intra-run normalization and inter-run calibration were performed by SomaLogic according to their SOMAscan assay GLP data quality-control procedures. Data from SomaLogic was reported in relative fluorescent units (RFU) after hybridization control normalization which remove individual sample variance on the basis of signalling differences between scans (herein referred to as RFU values). Data from all samples passed quality-control criteria and were considered eligible for further analysis. Limit of detection (LOD) was calculated as 3 times the standard deviation from the mean RFU signal measured from 3 blank samples. Median values for establishment of LOD and statistical analysis were calculated based on values in all samples. Proteins with RFU values below LOD were not considered for further analyses.

\section{Gene Ontology enrichment analysis}

To improve our understanding of the origin and functions of the proteins seen in PEx samples, a protein annotation enrichment analysis was performed, using the publicly available "Gene Ontology enrichment analysis and visualization tool GOrilla [26], matching a list of 199 uniquely mapped PEx proteins to either 
the Cellular Component (CC) or the Biological Process (BP) GO sub-domain (database updated on Feb 15, 2020). A list of 1291 uniquely mapped SOMAscan protein identities was used as reference/background.

\section{Statistical analysis}

Significance level for the Gene Ontology enrichment analysis was calculated using the right-tailed Fisher exact test, provided by the GOrilla web-based service [26]. Result from GO annotation enrichment analysis were considered significant at a Benjamini-Hochberg corrected $p$-value below 0.05. PEx protein composition was compared to that of BAL and enrichment factor was calculated by Fisher Exact test.

SOMAscan data were mainly analysed using Qlucore Omics Explorer 3.6 software (Qlucore, Lund, Sweden), and was log2 transformed, due to skewness. One-way analysis of variance (ANOVA) tests was used to determine intra-individual differences in groups of triplicate samples in the reproducibility experiment. General linear model (GLM), with each variable normalized to mean 0 and variance of 1 and adjustment for imbalance in BMI and/or age, was used to test differences between the NA, A and ASAD groups. Benjamini-Hochberg multiple correction was used to control for rate of false-positive results (herein referred to as q-value). Statistical analysis of clinical and demographic variables was performed with Kruskal-Wallis or Chi-square tests using Spotfire 7.0.2 software (TIBCO Spotfire).

Group comparisons of SOMAscan data were considered hypothesis free and proteins with $\mathrm{p}$ value below 0.05 and a Benjamini-Hochberg corrected p-value (q) below 0.2 was considered to be of interest in this explorative study.

\section{Results}

\section{Assessment of SOMAscan assay performance for PEx samples}

SOMAscan technical variability was evaluated by repeat measurements of a pooled PEx sample $(1 \mu \mathrm{g}$ PEx per $\mathrm{ml}$ ) 5 times on the SOMAscan $1.1 \mathrm{~K}$ platform. The mean CV value was $10 \%$ looking at a set of 174 proteins detected in all five samples, and below $20 \%$ for 156 of the 174 detected proteins (Figure 1 ). Intra-individual repeatability related to the PEx sampling procedure and the SOMAscan $1.1 \mathrm{~K}$ platform combined, was evaluated by repeat measurements of three consecutive $120 \mathrm{ng}$ PEx samples collected from 6 subjects with asthma. The CV values ranged from 6.1 to $24.8 \%$ with a mean of $13.8 \%$, looking at a set of 114 proteins detected in all 18 samples. Defining each of the 6 triplicate samples as groups, the between groups ANOVA test revealed 102 proteins with statistically significant differences between at least two of the group means $(\mathrm{q}<0.05)$. Filtering the list of protein variables further down to a q-value cutoff of $5.5^{\prime} 10^{-5}$ yielded 42 proteins that completely separated all 6 subjects from each other, as judged by visual inspection of a Principal Component Analysis (PCA) plot (Figure 2). 


\section{Assessment of pathological relevance of proteins detected in PEx samples}

Of the 1310 proteins represented on the 1.3K SOMAscan panel, 134 proteins showed RFU values larger than LOD in the complete set of 30 samples $(2 \mu \mathrm{g}$ PEx/ml). A set of 207 SOMAscan protein ID's, detected in up to $80 \%$ of the 30 samples were used for various comparative data analyses (Table S1A).

\subsection{Comparison of the protein composition of PEx with that of bronchoalveolar lavage fluid (BALF)}

Of 207 proteins detected using the SOMAscan 1.3K platform, 81 (41\%) have previously been detected in BALF [27]. Using 1323 uniquely mapped SOMAscan protein identities as reference/background gave at hand that PEx samples are enriched 5.9 times with the proteins previously detected in supernatant from BALF samples $(p<0.0001)$.

\subsection{Gene Ontology (GO) enrichment analysis}

Gene Ontology enrichment analysis of 199 uniquely mapped PEx/SOMAscan protein ID's (Figure 3) revealed an over-representation of several Cellular Components (CC) GO terms, for example; "extra cellular exosome" ( $\mathrm{EF}=1.79, \mathrm{q}=6.30 \mathrm{E}-11)$, "blood microparticle" ( $\mathrm{EF}=3.43, \mathrm{q}=8.28 \mathrm{E}-10)$ and "platelet alpha granule lumen" (EF=3.15, q=1.78E-04) (Table 2A). Biological Process (BP) GO domain analysis revealed an overrepresentation of BP terms, for example; "regulation of complement activation" ( $E F=4.4, q=5.17 \mathrm{E}-08$ ), "platelet degranulation" ( $\mathrm{EF}=2.8, \mathrm{q}=2.88 \mathrm{E}-04)$, "regulation of coagulation" ( $\mathrm{EF}=2.6, \mathrm{q}=2.72 \mathrm{E}-02)$, "acute inflammatory response" ( $\mathrm{EF}=3.21, \mathrm{q}=8.08 \mathrm{E}-03)$, and "neutrophil activation involved in immune response" $(E F=1.69, q=2.9 E-02)$ (Table 2B).

\subsection{Differential abundance analysis, asthma vs. non-asthma}

To identify confounding demographic factors we investigated the impact of gender, BMI and age. We found a clear effect of age and to some extent with $\mathrm{BMI}$, on the relative abundance of many proteins, independent of disease status. The relative abundance of each of the 207 detected proteins was then compared between various pairwise combinations of the ASAD, $(n=10), A(n=10)$ and NA $(n=10)$ groups. Adjusting for imbalance in age, 9 proteins were found to be differentially abundant in ASAD as compared to the NA group, whereof 2 were less abundant (ALDOA4, C4) and 7 more abundant in ASAD (FIGF, SERPINA1, CD93, CCL18, F10, IgM, IL1RAP) (Table S1), exemplified in Figure 4. Reviewing the scientific literature revealed that all of the 9 differentially abundant proteins are known to play role in immune response and respiratory disease (Table S2).

\subsection{Differential abundance analysis, ex-smokers vs. never smokers}


To explore effect of smoking, the 207 SOMAscan/PEx protein data set was screened for proteins showing differential abundance in ex-smokers $(n=14)$ vs. never smokers $(n=16)$. Only one protein, sRAGE (soluble Receptor for Advanced Glycation End products), a pattern-recognition receptor involved in host response to injury, infection and inflammation fulfilled the significance criteria after adjusting for age and $\mathrm{BMI}$, with significantly decreased abundance in ex-smokers as compared to never smokers (Figure 4). By contrast, SRAGE did not show any clear difference between any of the asthma groups and healthy control group.

\section{Discussion}

Exhalation after breath-holding at residual volume give rise to release of high numbers of tiny droplets/particles formed from the respiratory tract lining fluid covering the small airways. Some of these particles are small enough to float in the airstream of the exhalation and can be collected by impaction technology (PExA). Due to the small size of the particles and the specific origin, the total amount of RTLF that can be collected in this way is minute. In the present study we addressed the feasibility of proteomic profiling of PEx samples and we could demonstrate the SOMAscan proteomics platform is sensitive enough to detect and accurately quantify over 150 proteins in PEx samples from single individuals. Analysis of three consecutive samples from 6 subjects showed that PEx based proteomics data can be enough reproducible and informative to fully discriminate individuals from each other, suggesting that the method is useful for explorative studies of clinical samples. Moreover, protein enrichment analysis showed that protein composition of the PEx matrix resembles that of BALF supernatant to a large extent. This finding is important as it confirms previous findings $[19,28]$ and provide further confidence that PEX sample originate from small airways and hold the potential to be developed into a non-invasive substitute for bronchoscopy based diagnosis.

Protein enrichment analysis with reference to Gene Ontology (GO) "Cellular Component" sub-domain revealed that the PEx matrix is enriched in extracellular proteins associated with "exosome" (Figure 3, Table 2A). This finding is particularly interesting due to the emerging role of the exosomes as mediators of biomarkers for several chronic lung diseases [29, 30]. In addition, based on results from the GO "Biological Processes" domain analysis, PEx proteome seem highly relevant for studies on the role of innate immune response in development of respiratory diseases and host defence.

To explicitly explore the pathological relevance of the PEx proteome in studies of respiratory disease we analysed PEx/SOMAscan data from 20 asthma patients and 10 healthy control subjects. Despite the low number of subjects, we found several highly interesting proteins to be differently abundant in samples from ASAD as compared to the NA group (Table S1, S2 and Figure 4). Alfa-1-antitrypsin (SERPIN1A) and IL1RAP were elevated only in asthma patients with small airway dysfunction, as opposed to IgM, CD93 and CCL18 which were elevated also in asthma patients without small airway dysfunction (Figure 4A). The two different profiles suggest that SERPIN1A and IL1RAP may be specifically involved in small airway dysfunction, whereas IgM, CD93 and CCL18 may reflect disease processes less specific for small airway pathology. The observation that level of SRAGE, a protein suggested to be a blood based biomarker of smoking induced pathology $[31,32]$ was found to be abnormally low in PEx from ex- 
smokers, suggest that PEx samples is capable of reflecting long time effects of environmental challenges, an important feature for sub-phenotyping of disease.

There was a lack of significant differences in protein abundance comparing PEx from asthma patients with small airway involvement (ASAD) and those without (A). This may be due to that the A-group was younger than the other groups and that some actual difference might have been masked by the adjustment for age.

The present pilot study was small and primarily dimensioned to highlight the potential of PEx as a noninvasive method for collecting small airway samples compatible with protein biomarker analysis. The quantitative analysis showed however that the described method is sufficiently reproducible and sensitive to allow for detection of shifts in protein abundance profiles. Furthermore, the strong representation of proteins involved in innate immune responses and in the intersection between coagulation and inflammation in the PEx proteins with differential abundance in asthma vs. control samples, indicates that proteins measured in PEx samples convey pathophysiological information.

\section{Conclusion}

Our data illustrate for the first time how non-invasively retrieved respiratory tract lining fluid (RTLF), originating from the small airways in specific (PEx samples), can be analyzed with regard to the relative quantity of over 150 individual proteins. Data reveal that proteins present in PEx to a large extent seem to originate from extracellular vesicles whereof many are associated with innate immunity including the complement and coagulation system. Pathological relevance of PEx samples was further demonstrated by showing that all protein abundances found be statistically different between asthma patients with small airway dysfunction and healthy subjects are previously known to involved in lung disease pathways. Collectively our data is encouraging as it indicates that the PExA method provide a novel and non-invasive route to identify novel biomarkers and drug targets contributing to further development of precision medicine in respiratory disease.

\section{Abbreviations}

RFU: Relative Fluorescence Units

LOD: limit of detection

GLM: General Linear Model statistics

ANOVA: Analysis of variance

PCA: Principal Component Analysis

GLP: good laboratory practice

PExA: Particles in Exhaled Air, i.e. the method or instrument 
PEx: The sample or biological material collected with the PExA method

SAD: Small Airway Dysfunction

ELISA: enzyme-linked immunosorbent assay

LC/MS: Liquid chromatography-mass spectrometry

RTLF: Respiratory Tract Lining Fluid

EF: Enrichment Factor resulting from Gene Ontology enrichment analysis

mHG: minimal hypergeometric model

HG: hypergeometric model

\section{Declarations}

\section{Ethics approval and consent to participate}

The study was approved by the ethical committee at Gothenburg University, dnr 390-06.

And all participants gave their written informed consent to participate.

\section{Consent for publication}

Not applicable

\section{Availability of data and material}

The data and materials is unfortunately not publically available, the results are in the legal possession of Astra Zeneca

\section{Funding}

Thus study have been funded by AstraZeneca, and supported by The ChAMP (Centre for Allergy Research Highlights Asthma Markers of Phenotype) consortium which is funded by the Swedish Foundation for Strategic Research, the Karolinska Institute, AstraZeneca \& Science for Life Laboratory Joint Research Collaboration, and the Vårdal Foundation. It has also been funded by the Swedish research foundation for welfare

None of the funders have been involved in collection of the data. Jörgen Östling was during his employment at AZ involved analysing the data, and Jörgen Östling and Henric Olsson in the interpretation of the data and writing the manuscript, where also Marleen van Geest were involved.

\section{Competing interests}


Anna-Carin Olin is reporting competing interests as she is one of the inventors of the PExA method, and boardmember and chairholder of PEXA AB. Emilia Viklund is reporting a minor chairhold in PEXA AB. Dr Östling reports personal fees from PEXA AB during the conduct of the study; and Employed by PEXA AB while writing the manuscript but not during the planning and completion of the study.

\section{Authors' contributions}

Conceived the original idea - AO, MVG, JO

Designed the study - AO, MVG, JO

Planning of the study (groups, methods, ethics, analysis) AO, MVG, JO

Performed data collection - AO, EV

Performed data analysis - JO

Discussed the results - All authors

Supervised the project - AO

Wrote the paper - JÖ and AO with support from the other co-authors

Designed figures and tables - JÖ

Proofreading - All authors

\section{Acknowledgements}

We thank Marianne Andersson, Christina Ahlstrand and Helen Friberg for technical support and clinical work.

\section{References}

1. Postma DS, Brightling C, Baldi S, Van den Berge M, Fabbri LM, Gagnatelli A, Papi A, Van der Molen T, Rabe KF, Siddiqui S, Singh D, Nicolini G, Kraft M, group As. Exploring the relevance and extent of small airways dysfunction in asthma (ATLANTIS): baseline data from a prospective cohort study. Lancet Respir Med 2019: 7(5): 402-416.

2. in 't Veen JC, de Gouw HW, Smits HH, Sont JK, Hiemstra PS, Sterk PJ, Bel EH. Repeatability of cellular and soluble markers of inflammation in induced sputum from patients with asthma. Eur Respir $\mathrm{J}$ 1996: 9(12): 2441-2447.

3. Farah CS, King GG, Brown NJ, Downie SR, Kermode JA, Hardaker KM, Peters MJ, Berend N, Salome $\mathrm{CM}$. The role of the small airways in the clinical expression of asthma in adults. J Allergy Clin Immunol 2012: 129(2): 381-387, 387.e381. 
4. van der Wiel E, ten Hacken NH, Postma DS, van den Berge M. Small-airways dysfunction associates with respiratory symptoms and clinical features of asthma: a systematic review. The Journal of allergy and clinical immunology 2013: 131(3): 646-657.

5. van den Berge $\mathrm{M}$, ten Hacken $\mathrm{NH}$, van der Wiel E, Postma DS. Treatment of the bronchial tree from beginning to end: targeting small airway inflammation in asthma. Allergy 2013: 68(1): 16-26.

6. Telenga ED, van den Berge M, Ten Hacken NH, Riemersma RA, van der Molen T, Postma DS. Small airways in asthma: their independent contribution to the severity of hyperresponsiveness. The European respiratory journal : official journal of the European Society for Clinical Respiratory Physiology 2013: 41(3): 752-754.

7. Anderson WJ, Zajda E, Lipworth BJ. Are we overlooking persistent small airways dysfunction in community-managed asthma? Ann Allergy Asthma Immunol 2012: 109(3): 185-189 e182.

8. Hogg JC, Pare PD, Hackett TL. The Contribution of Small Airway Obstruction to the Pathogenesis of Chronic Obstructive Pulmonary Disease. Physiol Rev 2017: 97(2): 529-552.

9. Wright JR. Immunoregulatory functions of surfactant proteins. Nat Rev Immunol 2005: 5(1): 58-68.

10. Casals C, Campanero-Rhodes MA, Garcia-Fojeda B, Solis D. The Role of Collectins and Galectins in Lung Innate Immune Defense. Front Immunol 2018: 9: 1998.

11. Voelker DR, Numata M. Phospholipid regulation of innate immunity and respiratory viral infection. J Biol Chem 2019: 294(12): 4282-4289.

12. Wright SM, Hockey PM, Enhorning G, Strong P, Reid KB, Holgate ST, Djukanovic R, Postle AD. Altered airway surfactant phospholipid composition and reduced lung function in asthma. J Appl Physiol 2000: 89(4): 1283-1292.

13. Erpenbeck VJ, Malherbe DC, Sommer S, Schmiedl A, Steinhilber W, Ghio AJ, Krug N, Wright JR, Hohlfeld JM. Surfactant protein D increases phagocytosis and aggregation of pollen-allergen starch granules. Am J Physiol Lung Cell Mol Physiol 2005: 288(4): L692-698.

14. Enhorning G. Surfactant in airway disease. Chest 2008: 133(4): 975-980.

15. Mead J. The lung's "quiet zone". N Engl J Med 1970: 282(23): 1318-1319.

16. Almstrand AC, Bake B, Ljungstrom E, Larsson P, Bredberg A, Mirgorodskaya E, Olin AC. Effect of airway opening on production of exhaled particles. Journal of applied physiology 2010: 108(3): 584588.

17. Larsson P, Larstad M, Bake B, Hammar O, Bredberg A, Almstrand AC, Mirgorodskaya E, Olin AC. Exhaled particles as markers of small airway inflammation in subjects with asthma. Clin Physiol Funct Imaging 2017: 37(5): 489-497.

18. Kokelj S, Kim JL, Andersson M, Runstrom Eden G, Bake B, Olin AC. Intra-individual variation of particles in exhaled air and of the contents of Surfactant protein A and albumin. PLoS One 2020: 15(1): e0227980.

19. Behndig AF, Mirgorodskaya E, Blomberg A, Olin AC. Surfactant Protein A in particles in exhaled air (PExA), bronchial lavage and bronchial wash - a methodological comparison. Respir Res 2019: 20(1): 
214.

20. Horsley A. Lung clearance index in the assessment of airways disease. Respir Med 2009: 103(6): 793-799.

21. Quanjer PH, Tammeling GJ, Cotes JE, Pedersen OF, Peslin R, Yernault JC. Lung volumes and forced ventilatory flows. Report Working Party Standardization of Lung Function Tests, European Community for Steel and Coal. Official Statement of the European Respiratory Society. The European respiratory journal Supplement 1993: 16: 5-40.

22. Robinson PD, Latzin P, Verbanck S, Hall GL, Horsley A, Gappa M, Thamrin C, Arets HG, Aurora P, Fuchs SI, King GG, Lum S, Macleod K, Paiva M, Pillow JJ, Ranganathan S, Ratjen F, Singer F, Sonnappa S, Stocks J, Subbarao P, Thompson BR, Gustafsson PM. Consensus statement for inert gas washout measurement using multiple- and single- breath tests. The European respiratory journal 2013: 41(3): 507-522.

23. Kjellberg S, Houltz BK, Zetterstrom O, Robinson PD, Gustafsson PM. Clinical characteristics of adult asthma associated with small airway dysfunction. Respir Med 2016: 117: 92-102.

24. ATS/ERS recommendations for standardized procedures for the online and offline measurement of exhaled lower respiratory nitric oxide and nasal nitric oxide, 2005. Am J Respir Crit Care Med 2005: 171(8): 912-930.

25. Juniper EF, Svensson K, Mork AC, Stahl E. Modification of the asthma quality of life questionnaire (standardised) for patients 12 years and older. Health Qual Life Outcomes 2005: 3: 58.

26. Eden E, Navon R, Steinfeld I, Lipson D, Yakhini Z. GOrilla: a tool for discovery and visualization of enriched GO terms in ranked gene lists. BMC Bioinformatics 2009: 10: 48.

27. Ding Y, Xu H, Yao J, Xu D, He P, Yi S, Li Q, Liu Y, Wu C, Tian Z. Association between RTEL1 gene polymorphisms and COPD susceptibility in a Chinese Han population. Int $\mathrm{J}$ Chron Obstruct Pulmon Dis 2017: 12: 931-936.

28. Bredberg A, Gobom J, Almstrand AC, Larsson P, Blennow K, Olin AC, Mirgorodskaya E. Exhaled endogenous particles contain lung proteins. Clinical chemistry 2012: 58(2): 431-440.

29. Carnino JM, Lee H, Jin Y. Isolation and characterization of extracellular vesicles from Bronchoalveolar lavage fluid: a review and comparison of different methods. Respir Res 2019: 20(1): 240.

30. Ax E, Jevnikar Z, Cvjetkovic A, Malmhäll C, Olsson H, Rådinger M, Lässer C. T2 and T17 cytokines alter the cargo and function of airway epithelium-derived extracellular vesicles. Respiratory research 2020: 21(1): 155.

31. Sukkar MB, Wood LG, Tooze M, Simpson JL, McDonald VM, Gibson PG, Wark PA. Soluble RAGE is deficient in neutrophilic asthma and COPD. Eur Respir J 2012: 39(3): 721-729.

32. Gopal P, Reynaert NL, Scheijen JL, Schalkwijk CG, Franssen FM, Wouters EF, Rutten EP. Association of plasma sRAGE, but not esRAGE with lung function impairment in COPD. Respir Res 2014: 15: 24.

\section{Tables}


Table 1. - Demographic and clinical characteristics, including result from statistical tests 


\begin{tabular}{|c|c|c|c|c|c|c|}
\hline \multirow[b]{2}{*}{ Parameter } & \multirow[b]{2}{*}{$\begin{array}{l}\text { Non-asthma } \\
\text { (NA) }\end{array}$} & \multirow[b]{2}{*}{$\begin{array}{l}\text { Asthma } \\
\text { without SAD } \\
\text { (A) }\end{array}$} & \multirow[b]{2}{*}{$\begin{array}{l}\text { Asthma with } \\
\text { SAD (ASAD) }\end{array}$} & \multicolumn{2}{|c|}{ p-values } & \multirow[b]{2}{*}{$\begin{array}{l}\text { A vs. } \\
\text { NA }\end{array}$} \\
\hline & & & & $\begin{array}{l}\text { ASAD } \\
\text { vs. NA }\end{array}$ & $\begin{array}{l}\text { ASAD } \\
\text { vs. A }\end{array}$ & \\
\hline Number & 10 & 10 & 10 & & & \\
\hline $\begin{array}{l}\text { Gender } \\
\text { (Male/Female) }\end{array}$ & $7 / 3$ & $4 / 6$ & $3 / 7$ & $\begin{array}{l}7.36 \mathrm{E}- \\
2\end{array}$ & $\begin{array}{l}6.39 \mathrm{E}- \\
1\end{array}$ & $\begin{array}{l}1.78 \mathrm{E}- \\
1\end{array}$ \\
\hline Age & $\begin{array}{l}48.9(4.43) \\
{[28-66]}\end{array}$ & $\begin{array}{l}38.1(4.1) \\
{[20-59]}\end{array}$ & $\begin{array}{l}54.6(3.23) \\
{[38-68]}\end{array}$ & $\begin{array}{l}3.06 \mathrm{E}- \\
1\end{array}$ & $\begin{array}{l}4.06 \mathrm{E}- \\
3\end{array}$ & $\begin{array}{l}6.92 \mathrm{E}- \\
2\end{array}$ \\
\hline $\begin{array}{l}\text { Age at onset of } \\
\text { asthma, yrs }\end{array}$ & n.a & $\begin{array}{l}17.4(5.16) \\
{[5-55]}\end{array}$ & $\begin{array}{l}24.3(7.38) \\
{[2.0-60]}\end{array}$ & n.a & $\begin{array}{l}9.70 \mathrm{E}- \\
1\end{array}$ & n.a \\
\hline BMI & $\begin{array}{l}23.89(0.77) \\
{[19.26-27.16]}\end{array}$ & $\begin{array}{l}24.24(0.8) \\
{[21.15-28.34]}\end{array}$ & $\begin{array}{l}25.93(0.97) \\
{[21.47-31.18]}\end{array}$ & $\begin{array}{l}1.51 \mathrm{E}- \\
1\end{array}$ & $\begin{array}{l}2.26 \mathrm{E}- \\
1\end{array}$ & $\begin{array}{l}8.21 \mathrm{E}- \\
1\end{array}$ \\
\hline Allergy y/n & $3 / 7$ & $7 / 3$ & $6 / 4$ & $\begin{array}{l}1.78 \mathrm{E}- \\
1\end{array}$ & $\begin{array}{l}6.39 \mathrm{E}- \\
1\end{array}$ & $\begin{array}{l}7.36 \mathrm{E}- \\
2\end{array}$ \\
\hline Ex smoker y/n & $3 / 7$ & $4 / 6$ & $7 / 3$ & $\begin{array}{l}7.36 \mathrm{E}- \\
2\end{array}$ & $\begin{array}{l}1.78 \mathrm{E}- \\
1\end{array}$ & $\begin{array}{l}6.39 \mathrm{E}- \\
1\end{array}$ \\
\hline FEV1 (\% pred) & $\begin{array}{l}100.9(2.9) \\
{[88-117]}\end{array}$ & $\begin{array}{l}93.6(4.63) \\
{[79-123]}\end{array}$ & $\begin{array}{l}71.2(5.31) \\
{[39-91]}\end{array}$ & $\begin{array}{l}3.25 \mathrm{E}- \\
4\end{array}$ & $\begin{array}{l}5.13 \mathrm{E}- \\
3\end{array}$ & $\begin{array}{l}1.73 \mathrm{E}- \\
1\end{array}$ \\
\hline FEV1/FVC (\%) & $\begin{array}{l}75.13(7.67) \\
{[7.77-93.8]}\end{array}$ & $\begin{array}{l}79.2(2.11) \\
{[71-88]}\end{array}$ & $\begin{array}{l}62.69(3.73) \\
{[35-71]}\end{array}$ & $\begin{array}{l}2.49 \mathrm{E}- \\
3\end{array}$ & $\begin{array}{l}1.79 \mathrm{E}- \\
4\end{array}$ & $\begin{array}{l}4.05 \mathrm{E}- \\
1\end{array}$ \\
\hline Reversibility (\%) & $\begin{array}{l}2.4(1.66)[-5- \\
9]\end{array}$ & $\begin{array}{l}7.5(2.31)[1- \\
21]\end{array}$ & $\begin{array}{l}14.7(2.68)[6- \\
28]\end{array}$ & $\begin{array}{l}6.42 \mathrm{E}- \\
4\end{array}$ & $\begin{array}{l}1.37 \mathrm{E}- \\
2\end{array}$ & $\begin{array}{l}6.16 \mathrm{E}- \\
2\end{array}$ \\
\hline LCI z-score & $\begin{array}{l}0.89(0.12) \\
{[0.5-1.7]}\end{array}$ & $\begin{array}{l}1.04(0.17) \\
{[0-1.8]}\end{array}$ & $\begin{array}{l}5.07(0.53) \\
{[2.9-8.1]}\end{array}$ & $\begin{array}{l}1.54 \mathrm{E}- \\
4\end{array}$ & $\begin{array}{l}1.57 \mathrm{E}- \\
4\end{array}$ & $\begin{array}{l}3.43 \mathrm{E}- \\
1\end{array}$ \\
\hline $\begin{array}{l}\text { S-Cond VT, z- } \\
\text { score }\end{array}$ & $\begin{array}{l}-0.57(0.42) \\
{[-3-1.7]}\end{array}$ & $\begin{array}{l}-0.13(0.4) \\
{[-1.5-1.4]}\end{array}$ & $\begin{array}{l}3.77(0.49) \\
{[0.7-5.8]}\end{array}$ & $\begin{array}{l}2.10 \mathrm{E}- \\
4\end{array}$ & $\begin{array}{l}5.04 \mathrm{E}- \\
4\end{array}$ & $\begin{array}{l}6.22 \mathrm{E}- \\
1\end{array}$ \\
\hline $\begin{array}{l}\text { S-Acin VT, z- } \\
\text { score }\end{array}$ & $\begin{array}{l}0.59(0.18)[0- \\
1.5]\end{array}$ & $\begin{array}{l}0.48(0.21) \\
{[0-1.8]}\end{array}$ & $\begin{array}{l}2.76(0.81)[0- \\
8.6]\end{array}$ & $\begin{array}{l}7.77 \mathrm{E}- \\
3\end{array}$ & $\begin{array}{l}6.52 \mathrm{E}- \\
3\end{array}$ & $\begin{array}{l}4.82 \mathrm{E}- \\
1\end{array}$ \\
\hline GINA step & n.a. & $\begin{array}{l}2.2(0.29)[1- \\
4]\end{array}$ & $\begin{array}{l}2.9(0.41)[1- \\
4]\end{array}$ & n.a. & $\begin{array}{l}1.94 \mathrm{E}- \\
1\end{array}$ & n.a. \\
\hline $\begin{array}{l}\text { ACQ, mean (1- } \\
6)\end{array}$ & n.a. & $\begin{array}{l}0.82(0.3)[0- \\
3.17]\end{array}$ & $\begin{array}{l}1.13(0.24)[0- \\
2.17]\end{array}$ & n.a. & $\begin{array}{l}3.24 \mathrm{E}- \\
1\end{array}$ & n.a. \\
\hline $\begin{array}{l}\text { B-neutrophils } \\
(\%)\end{array}$ & $\begin{array}{l}3.01(0.33) \\
{[1.5-4.4]}\end{array}$ & $\begin{array}{l}3.68(0.35) \\
{[2.2-5.4]}\end{array}$ & $\begin{array}{l}4.53(0.52) \\
{[2.5-7.3]}\end{array}$ & $\begin{array}{l}4.93 \mathrm{E}- \\
2\end{array}$ & $2.4 \mathrm{E}-1$ & $\begin{array}{l}2.25 \mathrm{e}- \\
1\end{array}$ \\
\hline $\begin{array}{l}\text { B- } \\
\text { eosinophils(\%) }\end{array}$ & $\begin{array}{l}0.15(0.04) \\
{[0.06-0.5]}\end{array}$ & $\begin{array}{l}0.27(0.04) \\
{[0.1-0.6]}\end{array}$ & $\begin{array}{l}0.3(0.07) \\
{[0.1-0.6]}\end{array}$ & $\begin{array}{l}2.87 \mathrm{E}- \\
2\end{array}$ & $\begin{array}{l}8.44 \mathrm{E}- \\
1\end{array}$ & $\begin{array}{l}1.56 \mathrm{e}^{-} \\
\end{array}$ \\
\hline FENO, ppb & $\begin{array}{l}17.7(1.93)[8- \\
24]\end{array}$ & $\begin{array}{l}41.2(8.72) \\
{[6-86]}\end{array}$ & $\begin{array}{l}41.7(11.74) \\
{[11-113]}\end{array}$ & $\begin{array}{l}1.50 \mathrm{E}- \\
1\end{array}$ & $9.1 \mathrm{E}-1$ & $\begin{array}{l}6.91 \mathrm{E}- \\
2\end{array}$ \\
\hline
\end{tabular}




\begin{tabular}{|lllllll|} 
hsCRP & $0.51(0.08)$ & 0.432 & $2.35(0.62)$ & $5.46 \mathrm{E}-$ & $3.13 \mathrm{E}-$ & $3.06 \mathrm{E}-$ \\
& {$[0.23-1.1]$} & $(0.107)[0.14-$ & {$[0.45-5.40]$} & 3 & 3 & 1 \\
& $(\mathrm{n}=9)$ & $1.2]$ & & & & \\
\hline $\begin{array}{l}\text { Average mass } \\
\text { pg/particle }\end{array}$ & $0.23(0.01)$ & $0.22(0.01)$ & $0.22(0.01)$ & $6.93 \mathrm{E}-$ & $9.17 \mathrm{E}-$ & $5.08 \mathrm{E}-$ \\
& {$[0.2-0.27]$} & {$[0.18-0.3]$} & {$[0.17-0.29]$} & 1 & 1 & 1 \\
\hline
\end{tabular}

Data are presented as, means with standard error given in parenthesis and range given in brackets. Incomplete data is indicated by $\mathrm{n}$ numbers given in parenthesis. Kruskal Wallis and Chi Square statistical tests were used for analysing the differences between continuous and categorical data, respectively. "n.a." refer to test not applicable. 


\begin{tabular}{|c|c|c|c|c|c|}
\hline Description (term) & $\begin{array}{l}\text { Enrichment } \\
\text { factor }\end{array}$ & $\begin{array}{l}\text { Input and Output } \\
N, B, n, b\end{array}$ & $\begin{array}{l}\mathrm{p}- \\
\text { value }\end{array}$ & $\begin{array}{l}\text { FDR q- } \\
\text { value }\end{array}$ & GO term \\
\hline extracellular exosome & 1.79 & $1291,382,194,103$ & $\begin{array}{l}6.80 \mathrm{E}- \\
14\end{array}$ & $\begin{array}{l}6.30 \mathrm{E}- \\
11\end{array}$ & GO:0070062 \\
\hline extracellular vesicle & 1.78 & $1291,384,194,103$ & $\begin{array}{l}1.03 \mathrm{E}- \\
13\end{array}$ & $\begin{array}{l}3.19 \mathrm{E}- \\
11\end{array}$ & GO:1903561 \\
\hline extracellular region & 1.39 & $1291,566,194,118$ & $\begin{array}{l}1.92 \mathrm{E}- \\
07\end{array}$ & $\begin{array}{l}2.97 \mathrm{E}- \\
05\end{array}$ & GO:0005576 \\
\hline blood microparticle & 3.43 & $1291,62,194,32$ & $\begin{array}{l}3.57 \mathrm{E}- \\
12\end{array}$ & $\begin{array}{l}8.28 \mathrm{E}- \\
10\end{array}$ & GO:0072562 \\
\hline $\begin{array}{l}\text { platelet alpha granule } \\
\text { lumen }\end{array}$ & 3.15 & $1291,38,194,18$ & $\begin{array}{l}1.53 \mathrm{E}- \\
06\end{array}$ & $\begin{array}{l}1.78 \mathrm{E}- \\
04\end{array}$ & GO:0031093 \\
\hline extracellular matrix & 1.82 & $1291,183,194,50$ & $\begin{array}{l}2.12 \mathrm{E}- \\
06\end{array}$ & $\begin{array}{l}2.18 \mathrm{E}- \\
04\end{array}$ & GO:0031012 \\
\hline $\begin{array}{l}\text { collagen-containing } \\
\text { extracellular matrix }\end{array}$ & 1.91 & $1291,150,194,43$ & $\begin{array}{l}3.35 \mathrm{E}- \\
06\end{array}$ & $\begin{array}{l}3.11 \mathrm{E}- \\
04\end{array}$ & GO:0062023 \\
\hline cytoplasmic vesicle lumen & 1.92 & $1291,135,194,39$ & $\begin{array}{l}8.75 \mathrm{E}- \\
06\end{array}$ & $\begin{array}{l}6.76 \mathrm{E}- \\
04\end{array}$ & GO:0060205 \\
\hline $\begin{array}{l}\text { endoplasmic reticulum } \\
\text { lumen }\end{array}$ & 1.97 & $1291,91,194,27$ & $\begin{array}{l}1.61 \mathrm{E}- \\
04\end{array}$ & $\begin{array}{l}8.27 \mathrm{E}- \\
03\end{array}$ & GO:0005788 \\
\hline $\begin{array}{l}\text { endoplasmic reticulum } \\
\text { part }\end{array}$ & 1.71 & $1291,132,194,34$ & $\begin{array}{l}4.70 \mathrm{E}- \\
04\end{array}$ & $\begin{array}{l}2.18 \mathrm{E}- \\
02\end{array}$ & GO:0044432 \\
\hline
\end{tabular}

Table 2B. Gene ontology annotation enrichment analysis. Biological Process sub-domain (BP) 


\begin{tabular}{|c|c|c|c|c|c|}
\hline Description (term) & $\begin{array}{l}\text { Enrichment } \\
\text { factor }\end{array}$ & $\begin{array}{l}\text { Input and Output } \\
N, B, n, b\end{array}$ & $\begin{array}{l}\mathrm{p}- \\
\text { value }\end{array}$ & $\begin{array}{l}\text { FDR } \\
\text { q- } \\
\text { value }\end{array}$ & GO term \\
\hline $\begin{array}{l}\text { regulation of extracellular } \\
\text { matrix constituent secretion }\end{array}$ & 6.65 & $1291,5,194,5$ & $\begin{array}{l}7.33 \mathrm{E}- \\
05\end{array}$ & $\begin{array}{l}2.23 \mathrm{E}- \\
02\end{array}$ & G0:0003330 \\
\hline exocytosis & 1.80 & $1291,185,194,50$ & $\begin{array}{l}3.05 \mathrm{E}- \\
06\end{array}$ & $\begin{array}{l}1.54 \mathrm{E}- \\
03\end{array}$ & G0:0006887 \\
\hline vesicle-mediated transport & 1.74 & $1291,276,194,72$ & $\begin{array}{l}3.05 \mathrm{E}- \\
08\end{array}$ & $\begin{array}{l}2.78 \mathrm{E}- \\
05\end{array}$ & G0:0016192 \\
\hline secretion by cell & 1.63 & $1291,224,194,55$ & $\begin{array}{l}2.27 \mathrm{E}- \\
05\end{array}$ & $\begin{array}{l}8.63 \mathrm{E}- \\
03\end{array}$ & GO:0032940 \\
\hline $\begin{array}{l}\text { regulation of protein activation } \\
\text { cascade }\end{array}$ & 4.50 & $1291,34,194,23$ & $\begin{array}{l}2.28 \mathrm{E}- \\
12\end{array}$ & $\begin{array}{l}2.08 \mathrm{E}- \\
08\end{array}$ & GO:2000257 \\
\hline $\begin{array}{l}\text { regulation of complement } \\
\text { activation }\end{array}$ & 4.44 & $1291,33,194,22$ & $\begin{array}{l}1.13 \mathrm{E}- \\
11\end{array}$ & $\begin{array}{l}5.17 \mathrm{E}- \\
08\end{array}$ & G0:0030449 \\
\hline $\begin{array}{l}\text { complement activation, } \\
\text { alternative pathway }\end{array}$ & 4.44 & $1291,12,194,8$ & $\begin{array}{l}6.55 \mathrm{E}- \\
05\end{array}$ & $\begin{array}{l}2.14 \mathrm{E}- \\
02\end{array}$ & G0:0006957 \\
\hline $\begin{array}{l}\text { complement activation, } \\
\text { classical pathway }\end{array}$ & 3.90 & $1291,29,194,17$ & $\begin{array}{l}5.25 \mathrm{E}- \\
08\end{array}$ & $\begin{array}{l}4.36 \mathrm{E}- \\
05\end{array}$ & G0:0006958 \\
\hline $\begin{array}{l}\text { regulation of humoral immune } \\
\text { response }\end{array}$ & 3.64 & $1291,42,194,23$ & $\begin{array}{l}1.17 \mathrm{E}- \\
09\end{array}$ & $\begin{array}{l}1.77 \mathrm{E}- \\
06\end{array}$ & GO:0002920 \\
\hline innate immune response & 1.81 & $1291,114,194,31$ & $\begin{array}{l}3.04 \mathrm{E}- \\
04\end{array}$ & $\begin{array}{l}6.03 \mathrm{E}- \\
02\end{array}$ & G0:0045087 \\
\hline platelet degranulation & 2.80 & $1291,57,194,24$ & $\begin{array}{l}3.78 \mathrm{E}- \\
07\end{array}$ & $\begin{array}{l}2.88 \mathrm{E}- \\
04\end{array}$ & GO:0002576 \\
\hline fibrinolysis & 3.52 & $1291,17,194,9$ & $\begin{array}{l}2.67 \mathrm{E}- \\
04\end{array}$ & $\begin{array}{l}5.41 \mathrm{E}- \\
02\end{array}$ & GO:0042730 \\
\hline $\begin{array}{l}\text { negative regulation of } \\
\text { coagulation }\end{array}$ & 3.21 & $1291,29,194,14$ & $\begin{array}{l}1.86 \mathrm{E}- \\
05\end{array}$ & $\begin{array}{l}7.37 \mathrm{E}- \\
03\end{array}$ & G0:0050819 \\
\hline regulation of coagulation & 2.60 & $1291,41,194,16$ & $\begin{array}{l}1.19 \mathrm{E}- \\
04\end{array}$ & $\begin{array}{l}2.72 \mathrm{E}- \\
02\end{array}$ & GO:0050818 \\
\hline regulation of haemostasis & 2.60 & $1291,41,194,16$ & $\begin{array}{l}1.19 \mathrm{E}- \\
04\end{array}$ & $\begin{array}{l}2.86 \mathrm{E}- \\
02\end{array}$ & GO:1900046 \\
\hline acute-phase response & 3.33 & $1291,24,194,12$ & $\begin{array}{l}4.93 \mathrm{E}- \\
05\end{array}$ & $\begin{array}{l}1.67 \mathrm{E}- \\
02\end{array}$ & G0:0006953 \\
\hline acute inflammatory response & 3.21 & $1291,29,194,14$ & $\begin{array}{l}1.86 \mathrm{E}- \\
05\end{array}$ & $\begin{array}{l}8.08 \mathrm{E}- \\
03\end{array}$ & GO:0002526 \\
\hline $\begin{array}{l}\text { neutrophil activation involved } \\
\text { in immune response }\end{array}$ & 1.69 & $1291,126,194,32$ & $\begin{array}{l}9.28 \mathrm{E}- \\
04\end{array}$ & $\begin{array}{l}1.69 \mathrm{E}- \\
01\end{array}$ & G0:0002283 \\
\hline
\end{tabular}


regulation of response to external stimulus

defence response
1.48

1.40
$1291,287,194,64$

$1.14 \mathrm{E}$

04

$1291,300,194,63$
$8.92 \mathrm{E}-$ 04
$2.90 \mathrm{E}-$

02

1.70E- GO:0006952 01

Table 2 display result from Gene Ontology enrichment analysis using the publicly available "Gene Ontology enrichment analysis and visualization tool" (GOrilla) [26]. A list of 199 uniquely mapped PEx proteins detected with SOMAscan 1.3K were searched against the Cellular Component sub-domain database (2A) and the Biological Process sub-domain database (2B). A list of 1291 uniquely mapped SOMAscan 1.3K protein identities was used as reference/background. Enrichment factor was calculated as $(b / n) /(B / N)$, where $n$ - is the total number of PEx protein ID's, identified by SOMAscan and used as input, $b$ - is the number of PEx /SOMAscan protein ID's associated with the GO term. $p$ values for enrichment analysis were computed according to the $\mathrm{mHG}$ or $\mathrm{HG}$ model. FDR $q$ value is the $p$ value corrected for multiple testing using the Benjamini and Hochberg (1995) method

\section{Figures}

Fig 1

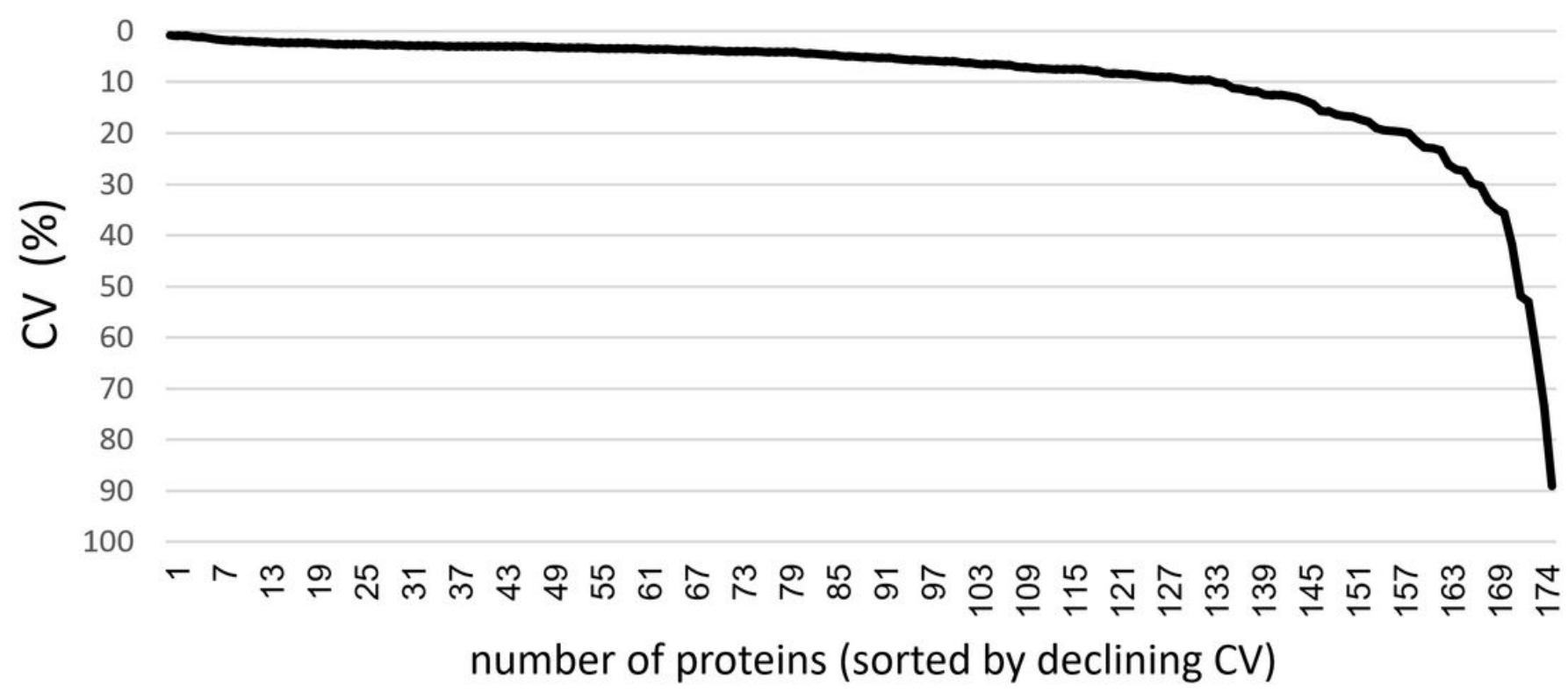

\section{Figure 1}

Distribution of $\mathrm{CV}$ for 174 proteins detected in a pooled PEx sample $(1 \mu \mathrm{g}$ PEx $/ \mathrm{ml})$, analysed 5 times with the SOMAscan $1.1 \mathrm{~K}$ platform. The pooled sample originated from 6 subjects with asthma and 3 healthy volunteers. Proteins were considered detected if RFU values delivered by SomaLogic were larger than LOD 
in all 5 replicate samples. Limit of detection (LOD) was calculated as 3 times the standard deviation from the mean RFU signal measured from 3 blank samples.

\section{Fig 2.}

6 asthmatics

$\square 1 \square 4$
$\square 2 \square 5$
$\square 3 \square 6$

PCA plot

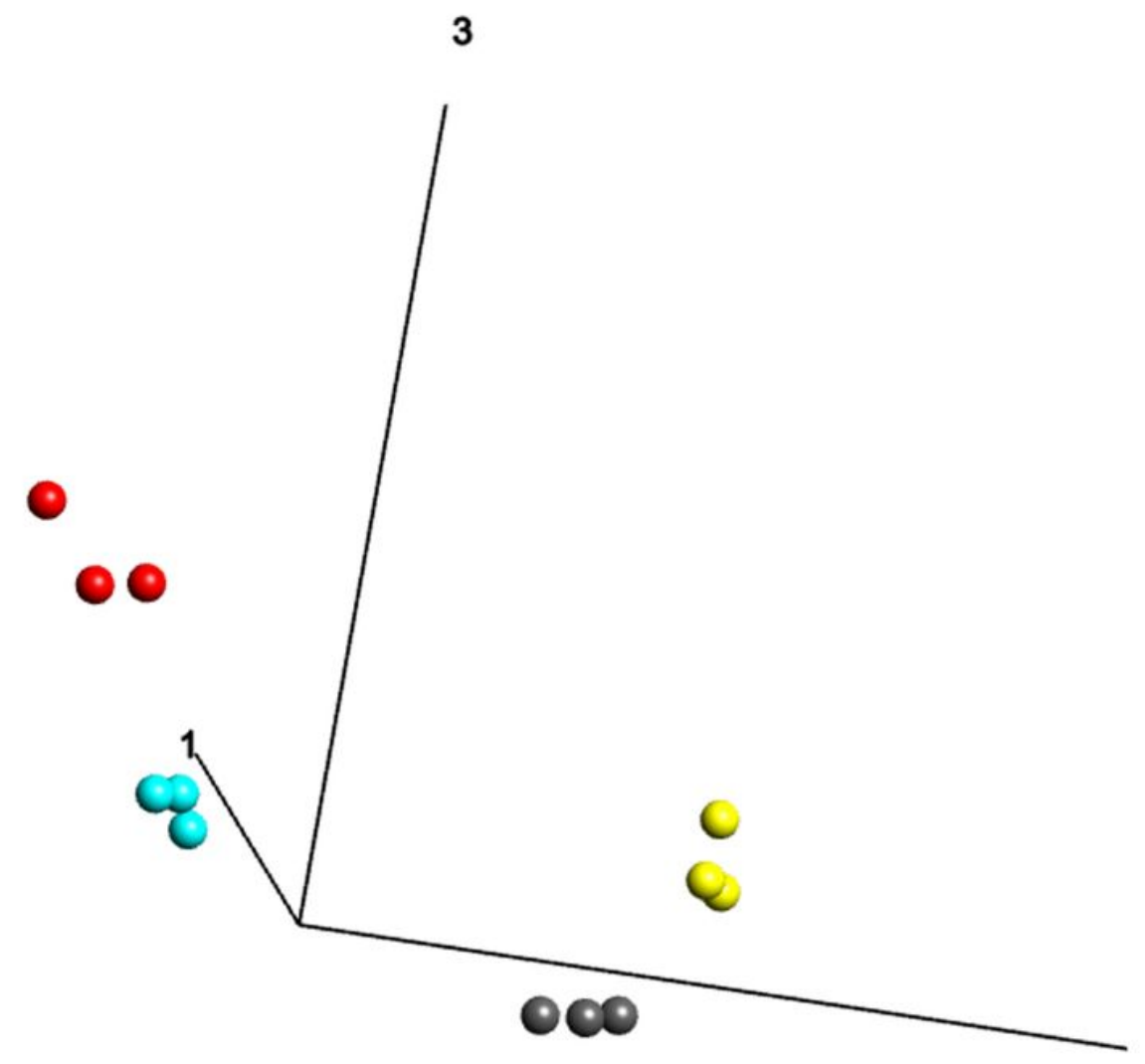

\section{Figure 2}

Assessment of intra-individual variability by visual inspection of Principle Component Analysis (PCA) plot. PEx samples from 3 consecutive PEx samples from 6 asthmatic subjects (red, blue, green, white, black and yellow) were analysed with the SOMAscan $1.1 \mathrm{~K}$ platform. Using ANOVA statistical test based variable selection ( $\mathrm{q}<5.5 \mathrm{E}-5) 42$ out of 114 proteins commonly detected in all 18 samples, were found to discriminate all 6 subjects from each other in a PCA plot, as judged by visual inspection in Omics Explorer software. 
Fig 3

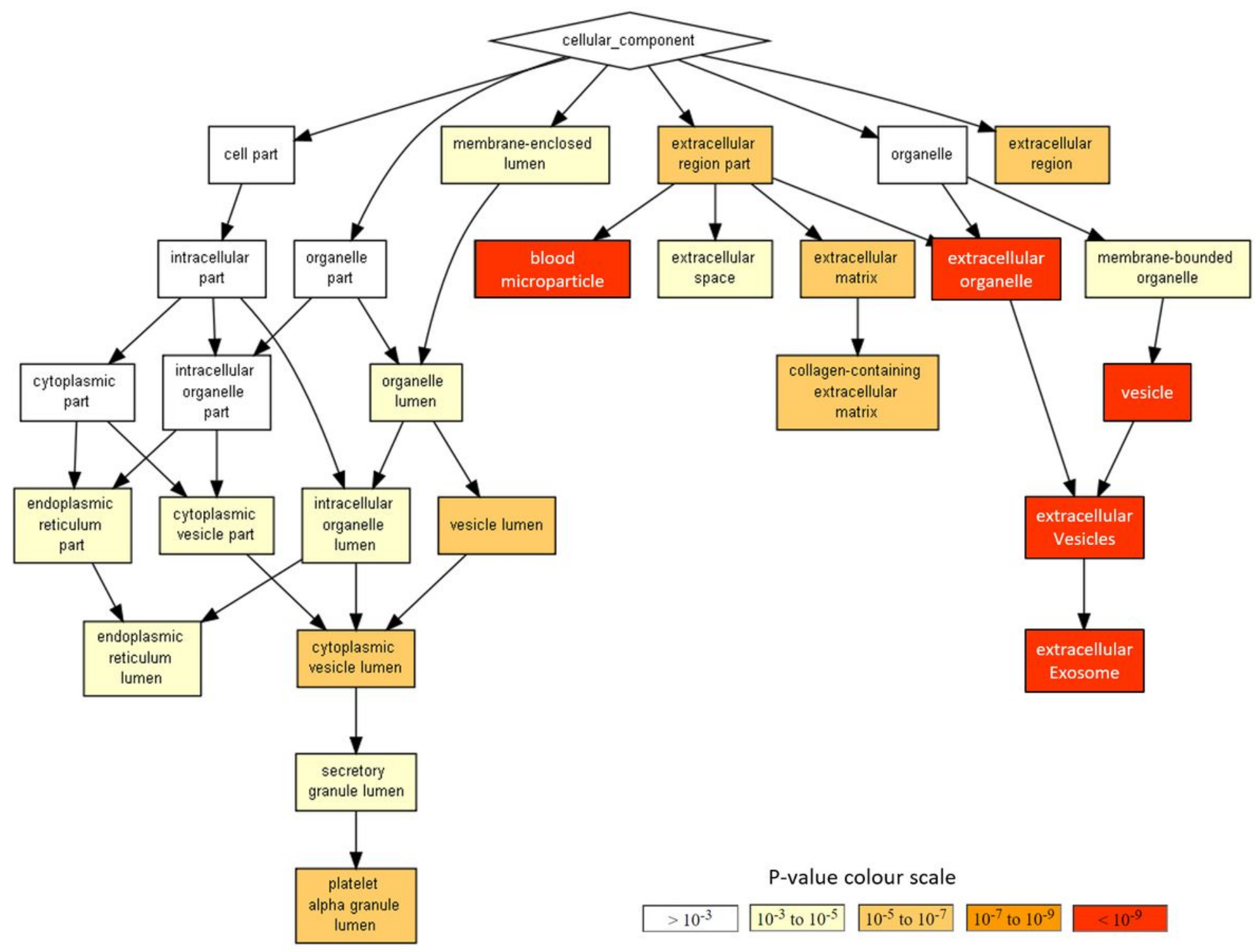

Figure 3

Visualization of results from Gene Ontology (GO) enrichment analysis (GOrilla [26]) matching 207 proteins detected in PEx samples by SOMAscan 1.3K platform, to the GO Cellular Component sub-domain database. Over represented GO terms are organized in a parent-child based hierarchically structure with color-coded significance levels (Fisher's exact test), as indicated in the p-value colour scale. 
Fig 4
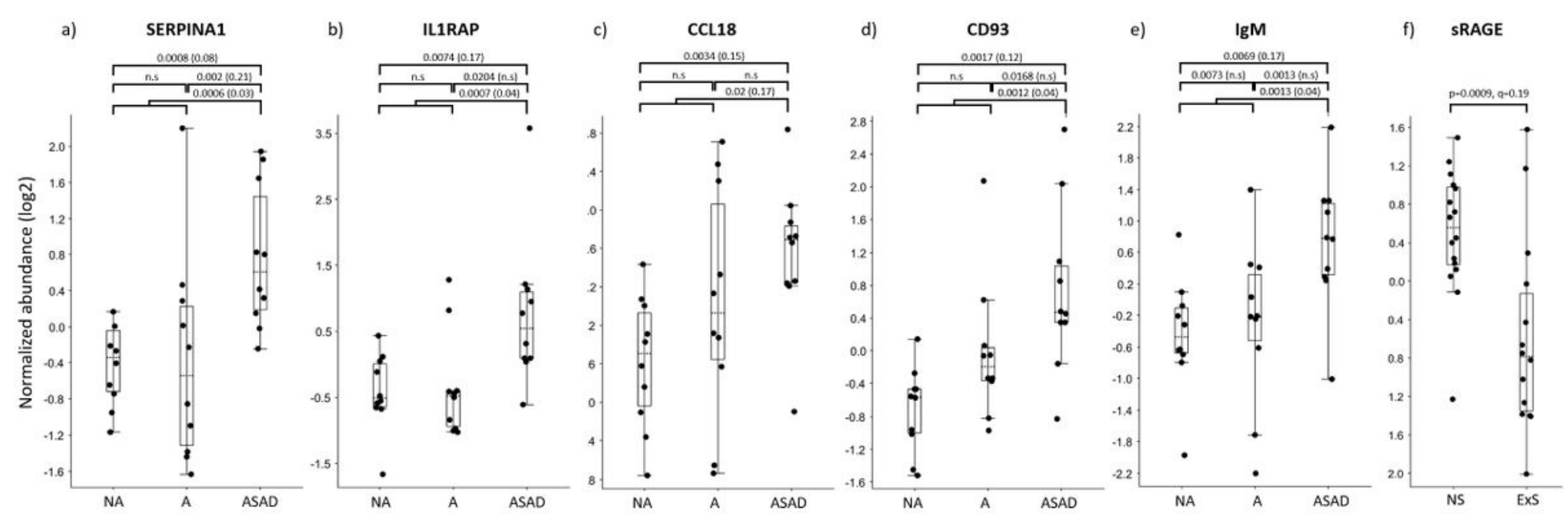

Figure 4

Box plots show examples of SOMAscan data for 6 differentially abundant proteins; a) Alpha-1-antitrypsin (SERPINA1), b) Interleukin-1 Receptor accessory protein (IL1RAP), c) CC motif chemokine 18 (CCL18), d) Complement component C1q receptor (CD93), e) Immunoglobulin M (IgM), in non-asthma (NA), asthma without (A) and with small airway dysfunction (ASAD), and f) Soluble Receptor of Advanced Glycation End products (SRAGE) in never-smokers (NS) and ex-smokers (ExS). Y-axis show normalized abundance ( $\log 2$ transformation and normalization to mean 0 and variance 1 ). Box ranges from the 25th to the 75 th percentile and median value is marked with dotted line. $p$ values and false discovery rate adjusted $p$ values (q) from various pairwise comparisons are shown over each box plot.

\section{Supplementary Files}

This is a list of supplementary files associated with this preprint. Click to download.

- Ostlingetal2020Supplementarymaterial.docx 